\title{
PENGARUH SERBUK CANGKANG TELUR AYAM DAN PUPUK NPK 16:16:16 TERHADAP PERTUMBUHAN DAN PRODUKSI TANAMAN TOMAT (Lycopersicum esculentum Mill.)
}

\author{
The Effect of Chicken Eggshell Powder and NPK 16:16:16 on Plant Growth \\ and Yield of Tomato (Lycopersicum esculentum Mill.)
}

\author{
Roni Setiawan, Saripah Ulpah, dan Raisa Baharuddin* \\ Program Studi Agroteknologi, Fakultas Pertanian Islam Riau, \\ Jl. Kaharuddin Nasution No. 113 Pekanbaru.28284. Telp: 0761-674681; Fax : 0761-674681 \\ *Email korespodensi: raisabaharuddin@agr.uir.ac.id \\ [Diterima: Oktober 2019; Disetujui: Desember 2019]
}

\begin{abstract}
Tomato (Lycopersicum esculentum Mill.) is one of the vegetables that have high economic value. However, tomato production in Riau is constrained by low fertility and acidity. Egg shell waste can be used as a substitute for lime to increase soil pH. NPK fertilizer is used to provide nutrients for plants. This study aims to determine the effect of chicken eggshell powder and NPK 16:16:16 fertilizer on the growth and yield of tomato plants. This research was conducted in the experimental farm of the Faculty of Agriculture, Riau Islamic University, Pekanbaru. The study was conducted from March to July 2019. The study was conducted using a completely randomized design (CRD) with 16 treatments and repeated 3 times. The first factor was chicken eggshell powder with 4 levels $(0,15,30,45 \mathrm{~g} / \mathrm{plant})$ and the second factor was NPK fertilizer 16:16:16 with 4 levels $(0,10,20,30 \mathrm{~g} / \mathrm{plant})$. The results showed that the interactions occurred in the number of fruits per plant, fruit weight per plant on reatments for $45 \mathrm{~g}$ of chicken eggshell powder/plant and NPK 16:16:16 $30 \mathrm{~g} / \mathrm{plant}$.
\end{abstract}

Keywords: Egg Shell, Lime, NPK, $p H$

\begin{abstract}
ABSTRAK
Tomat (Lycopersicum esculentum Mill.) merupakan salah satu sayuran utama yang memiliki nilai ekonomi tinggi. Namun produksi tomat di Riau terkendala kesburan tanah rendah dan masam. Pemanfaatan limbah cangkang telur dapat dijadikan bahan pengganti kapur untuk peningkatan $\mathrm{pH}$ tanah. Pupuk NPK digunakan untuk menyediakan unsur hara bagi tanaman. Penelitian ini bertujuan untuk mengetahui pengaruh serbuk cangkang telur ayam dan pupuk NPK 16:16:16 terhadap pertumbuhan dan hasil tanaman tomat. Penelitian ini telah dilaksanakan di kebun percobaan Fakultas Pertanian Universitas Islam Riau, Pekanbaru. Penelitian dilakukan pada bulan Maret-Juli 2019. Penelitian dilakukan dengan menggunakan Rancangan Acak Lengkap (RAL) dengan 16 perlakuan yang diulang 3 kali. Faktor pertama adalah serbuk cangkang telur ayam dengan 4 taraf $(0,15,30,45$ g/tanaman) dan faktor kedua adalah pupuk NPK 16:16:16 dengan 4 taraf $(0,10,20,30 \mathrm{~g} /$ tanaman). Hasil penelitian menunjukkan bahwa terjadi interaksi pada jumlah buah per tanaman, berat buah per tanaman dengan perlakuan serbuk cangkang telur ayam $45 \mathrm{~g} /$ tanaman dan pupuk NPK 16:16:16 30 g/tanaman.
\end{abstract}

Kata kunci: Cangkang Telur, Kapur, NPK, $p H$

\section{PENDAHULUAN}

Tomat merupakan salah satu sayuran utama yang memiliki nilai ekonomi tinggi. Permintaan akan buah tomat setiap tahunnya terus meningkat. Hal ini yang membuat tanaman tomat dibudidayakan di seluruh daerah di Indonesia, salah satunya di Riau. Namun, produksi tomat di provinsi Riau mssih berfluktuasi dikarenakan suhu yang relatif tinggi, serangan hama dan penyakit, kesuburan tanah rendah dan $\mathrm{pH}$ tanah rendah (kemasaman tinggi) (Purwati, 2009).

Kendala kemasamam tanah tinggi dapat diatasi dengan penggunaan kapur untuk meningkatkan $\mathrm{pH}$ tanah. Namun harganya cukup mahal dan akan meningkatkan biaya produksi dalam budidaya tanaman tomat. Sehingga diperlukan alternatif bahan lainnya 
sebagai pengganti kapur, salah satunya adalah cangkang telur ayam.

Limbah cangkang telur ayam mengalami peningkatan seiring meningkatnya konsumsi telur di masyarakat. Namun saat ini pemanfaatan cangkang telur belum menjadi perhatian. Cangkang telur mengandung $97 \%$ kalsium karbonat, 3\% fosfor dan 3\% magnesium (Gary et al., 2009). Sehingga berpotensi sebagai alternatif kapur untuk meningkatkan $\mathrm{pH}$ tanah. Selain itu kalsium yang terdapat pada cangkang telur ayam juga mampu mengatasi permasalahan penyakit blossom-end rot atau busuk ujung buah yang menurunkan kualitas buah tomat. Syahren, dkk (2012) mengungkapkan bahwa aplikasi pupuk kalsium dapat mengurangi timbulnya blossomend rot secara drastis.

Peningkatan produksi tomat juga dapat dilakukan dengan penambahan unsur hara dengan pemupukan NPK. Pupuk NPK 16:16:16 merupakan pupuk majemuk yang mengandung 3 unsur hara esensial yaitu unsur $\mathrm{N}$ (nitrogen), P (fosfor) dan K (kalium). Pupuk NPK dapat meningkatkan pertumbuhan dan produksi tomat.

Tujuan penelitian ini adalah mengetahui pengaruh serbuk cangkang telur ayam dan pupuk NPK 16:16:16 terhadap pertumbuhan dan produksi tanaman tomat.

\section{METODE PENELITIAN}

Penelitian ini telah dilaksanakan di Kebun Percobaan Fakultas Pertanian Universitas Islam Riau, Pekanbaru. Penelitian dilaksanakan pada bulan Maret hingga Juli 2019. Bahan yang digunakan dalam penelitian ini adalah cangkang telur ayam, benih tomat varietas Servo F1, pupuk NPK 16:16:16, tanah lapisan atas, pupuk bokashi, polibag $(8 \times 12$ $\mathrm{cm}$ ), polibag $(35 \times 40 \mathrm{~cm})$, Furadan $3 \mathrm{GR}$ dan Curacron 500 EC. Alat yang digunakan dalam penelitian ini yaitu cangkul, blender, garu, meteran, gembor, handsprayer, timbangan analitik, kuas, kayu, gunting, kamera dan alatalat tulis.

Rancangan yang digunakan yaitu Rancangan Acak Lengkap (RAL) dengan 3 ulangan. Faktor pertama adalah serbuk cangkang telur ayam (Faktor C) terdiri dari 4 taraf perlakuan, yaitu tanpa serbuk cangkang telur ayam (C0), serbuk cangkang telur ayam $15 \mathrm{~g} /$ tanaman $(\mathrm{C} 1)$, serbuk cangkang telur ayam $30 \mathrm{~g} / \operatorname{tanaman}$ (C2), dan serrbuk cangkang telur ayam 45 g/tanaman (C3). Faktor kedua adalah pupuk NPK 16:16:16 (Faktor N) terdiri dari 4 taraf perlakuan, yaitu tanpa pupuk NPK (N0), NPK 10 g/tanaman (N1), NPK 20 g/tanaman (N2), dan NPK 30 g/tanaman (N3).

Cangkang telur ayam yang digunkan adalah cangkang yang telah dikeringkan dengan cara dijemur dibawah sinar matahari selama 2 hari. Kemudian diremukkan dan diblender sampai halus. Untuk menghasilkan serbuk cangkang telur yang halus, dilakukan pengayakan. Untuk mendapatkan $1 \mathrm{~kg}$ serbuk cangkang telur ayam, membutuhkan \pm 250 cangkang telur ayam. Pemberian serbuk cangkang telur ayam dilakukan satu kali yaitu 2 minggu sebelum tanam, dengan mencampurkannya ke dalam media tanam dalam polibag.

Parameter pengamatan pada tanaman tomat yaitu tinggi tanaman, jumlah cabang, jumlah buah per tanaman, berat per buah, dan berat per tanaman. Data yang diperoleh dianalisis menggunakan analisis ragam (uji $\mathrm{F}$ ) pada taraf 5\% dengan uji lanjut BNJ.

\section{HASIL DAN PEMBAHASAN}

\section{Tinggi Tanaman $(\mathrm{cm})$}

Hasil pengamatan tinggi tanaman dengan perlakuan serbuk cangkang telur ayam dan pupuk NPK 16:16:16 disajikan pada Tabel 1.

Tabel 1 menunjukkan bahwa perlakuan serbuk cangkang telur ayam (C1-C3) menghasilkan tinggi tanaman yang lebih tinggi dari perlakuan kontrol $(\mathrm{C} 0)$. Hal ini disebabkan oleh kalsium $(\mathrm{Ca})$ yang terdapat pada serbuk cangkang telur ayam berperan dalam mendorong perkembangan akar dan pertumbuhan tanaman karena terlibat dalam pemanjangan akar, pemajnagan sel, sintesis protein dan pembelahan sel (Dahang dkk, 2019). Syam, dkk (2014) menambahkan bahwa kalsium berperan penting pada titik tumbuh akar dengan mengatur daya tembus akar, serta merawat dinding sel. Kekurangan kalsium dapat menyebabkan tanaman tetap tumbuh tinggi namun tidak kokoh karena titik tumbuh lemah. Perkembangan akar tanaman ditunjukkan dengan pembentukan rambut akar sehingga tanaman dapat menyerap air dan mineral hara dengan optimal (Datta dkk, 2011). Oleh karena itu pertumbuhan tanaman meningkat seperti pada tinggi tanaman. 
Tabel 1. Rata-rata Tinggi Tanaman Tomat 56 Hari Setelah Tanam dengan Perlakuan Serbuk Cangkang Telur Ayam dan Pupuk NPK 16:16:16 (cm).

\begin{tabular}{lrllll}
\hline \multirow{2}{*}{$\begin{array}{c}\text { Cangkang telur ayam } \\
(\mathrm{g} / \text { tanaman })\end{array}$} & $0(\mathrm{~N} 0)$ & $10(\mathrm{~N} 1)$ & $20(\mathrm{~N} 2)$ & $30(\mathrm{~N} 3)$ & \multirow{2}{*}{ Rata-rata } \\
\cline { 2 - 5 } & 90,83 & 104,00 & 109,33 & 110,00 & $103,54 \mathrm{~b}$ \\
$15(\mathrm{C} 1)$ & 108,17 & 104,17 & 113,83 & 111,50 & $109,42 \mathrm{ab}$ \\
$30(\mathrm{C} 2)$ & 100,67 & 110,83 & 110,83 & 109,17 & $107,88 \mathrm{ab}$ \\
$45(\mathrm{C} 3)$ & 107,17 & 110,00 & 123,00 & 126,83 & $116,75 \mathrm{a}$ \\
\hline Rata-rata & $101,71 \mathrm{~b}$ & $107,25 \mathrm{ab}$ & $114,25 \mathrm{a}$ & $114,38 \mathrm{a}$ \\
\hline KK $=8,59 \%$ & \multicolumn{5}{c}{ BNJ C\&N =10,41 } \\
\hline
\end{tabular}

Angka-angka pada baris dan kolom yang diikuti huruf kecil yang sama menandakan tidak berbeda nyata menurut uji lanjut BNJ taraf 5\%.

Selain itu kalsium juga dapat meningkatkan unsur $\mathrm{N}$ dalam tanah (Barman, $\mathrm{dkk}$, 2014). Sehingga tingginya serapan N akan meningkatkan pertumbuhan tanaman seperti tinggi tanaman, jumlah daun, bobot segar dan kering tanaman (Prasetya, dkk, 2009).

Tabel 1 juga menunjukkan perlakuan pupuk NPK 16:16:16 (N1-N3) nyata meningkatkan tinggi tanaman tomat dibandingkan dengan tanpa pupuk. Hal ini dikarenakan pupuk NPK mencukupi kebutuhan unsur hara nitrogen, fosfor, dan kalium yang diperlukan tanaman untuk meningkatkan pertumbuhan. Dalam pertumbuhan tanaman tanaman tomat membutuhkan nitrogen dalam jumlah banyak. Menurut Subhan, dkk (2009) nitrogen merupakan komponen dasar dalam sintesis protein. Nitrogen terdapat dalam protoplasma sel tanaman yang diperlukan untuk semua proses pertumbuhan. Sejalan dengan Duaja (2012) yang menyatakan bahwa tanaman lebih menggunakan unsur $\mathrm{N}$ untuk pertumbuhan pucuk dibanding dengan pertumbuhan akar, sehingga unsur $\mathrm{N}$ lebih berpengaruh dalam pertumbuhan tinggi tanaman.

\section{Jumlah Cabang (buah)}

Hasil pengamatan jumlah cabang dengan perlakuan serbuk cangkang telur ayam dan pupuk NPK 16:16:16 setelah dianalisis menunjukkan bahwa pengaruh utama serbuk cangkang telur ayam dan pupuk NPK 16:16:16 berpengaruh nyata terhadap jumlah cabang, disajikan pada Tabel 2. Tabel 2 menunjukkan bahwa perlakuan C3 (serbuk cangkang telur ayam $45 \mathrm{~g} /$ tanaman) memiliki jumlah cabang terbanyak 6,13 buah dan berbeda nyata dengan perlakuan lainnya.

Tabel 2. Rata-rata Jumlah Cabang Tomat dengan Perlakuan Serbuk Cangkang Telur Ayam dan Pupuk NPK 16:16:16 (Buah)

\begin{tabular}{|c|c|c|c|c|c|}
\hline \multirow{2}{*}{$\begin{array}{c}\text { Cangkang telur ayam } \\
\text { (g/tanaman) }\end{array}$} & \multicolumn{4}{|c|}{ Pupuk NPK 16:16:16 (g/tanaman) } & \multirow{2}{*}{ Rata-rata } \\
\hline & $0(\mathrm{~N} 0)$ & $10(\mathrm{~N} 1)$ & $20(\mathrm{~N} 2)$ & $30(\mathrm{~N} 3)$ & \\
\hline $0(\mathrm{C} 0)$ & 4,00 & 4,67 & 4,83 & 5,17 & $4,67 \mathrm{c}$ \\
\hline $15(\mathrm{C} 1)$ & 4,67 & 4,83 & 5,50 & 5,50 & $5,13 \mathrm{bc}$ \\
\hline $30(\mathrm{C} 2)$ & 4,33 & 5,50 & 6,00 & 6,50 & $5,58 \mathrm{~b}$ \\
\hline $45(\mathrm{C} 3)$ & 5,50 & 6,00 & 6,00 & 7,00 & $6,13 \mathrm{a}$ \\
\hline Rata-rata & $4,63 \mathrm{c}$ & $5,25 \mathrm{~b}$ & $5,58 \mathrm{ab}$ & $6,04 \mathrm{a}$ & \\
\hline $\mathrm{KK}=9,01 \%$ & \multicolumn{4}{|c|}{ BNJ C \& N =0,54 } & \\
\hline
\end{tabular}

Angka-angka pada baris dan kolom yang diikuti huruf kecil yang sama menandakan tidak berbeda nyata menurut uji lanjut BNJ taraf $5 \%$.

Tabel 2 juga menunjukkan bahwa semakin tinggi dosis serbuk cangkang telur ayam maka akan mempengaruhi cabang tanaman tomat. Semakin banyaknya cabang maka diduga semakin banyak kesempatan untuk muncul bunga lebih besar, sehingga berdampak pada jumlah buah tomat.

Data pada Tabel 2 menunjukkan bahwa pengaruh utama pupuk NPK 16:16:16 berpengaruh nyata terhadap jumlah cabang tanaman tomat, dimana perlakuan N3 (30 g/tanaman) memberikan jumlah cabang terbanyak 6,04 buah dan tidak berbeda nyata dengan perlakuan N2 (20 g/tanaman), namun berbeda nyata dengan perlakuan lainnya.

Perlakuan pupuk NPK 16:16:16 20-30 g/tanaman (C2 dan C3) memberikan jumlah cabang terbanyak, hal itu dikarenakan 
penambahan pupuk NPK memberikan unsur N, P dan K tersedia bagi tanaman. Marliah (2012) menyatakan bahwa pertumbuhan dan hasil tomat akan lebih baik apabila semua unsur yang dibutuhkan oleh tanaman berada dalam keadaan yang tersedia dan cukup.

\section{Jumlah Buah Per Tanaman (buah)}

Hasil pengamatan menunjukkan bahwa perlakuan serbuk cangkang telur ayam dan pupuk NPK 16:16:16 berpengaruh nyata secara interaksi dan utama terhadap jumlah buah per tanaman (Tabel 3). Tabel 3 menunjukkan bahwa perlakuan serbuk cangkang telur ayam $45 \mathrm{~g} /$ tanaman dan pupuk NPK 16:16:16 $30 \mathrm{~g} / \operatorname{tanaman}(\mathrm{C} 3 \mathrm{~N} 3)$ nyata memiliki jumlah buah pertanaman terbanyak yaitu 27,00 buah, dan berbeda nyata dengan perlakuan lainnya. Hal ini dikarenakan unsur hara yang diberikan dari serbuk cangkang telur ayam dan pupuk NPK 16:16:16 mampu mencukupi kebutuhan hara yang diperlukan tanaman pada saat pembentukan buah.

Tabel 3. Jumlah Buah Per Tanaman Tomat dengan Perlakuan Serbuk Cangkang Telur Ayam dan Pupuk NPK 16:16:16 (buah)

\begin{tabular}{|c|c|c|c|c|c|}
\hline \multirow{2}{*}{$\begin{array}{c}\text { Cangkang telur } \\
\text { ayam (g/tanaman) }\end{array}$} & \multicolumn{4}{|c|}{ Pupuk NPK 16:16:16 (g/tanaman) } & \multirow{2}{*}{ Rata-rata } \\
\hline & $0(\mathrm{~N} 0)$ & 10 (N1) & $20(\mathrm{~N} 2)$ & $30(\mathrm{~N} 3)$ & \\
\hline $0(\mathrm{C} 0)$ & $9,17 \mathrm{i}$ & $13,50 \mathrm{gh}$ & $14,00 \mathrm{fgh}$ & $17,33 \mathrm{c}-\mathrm{f}$ & $13,50 \mathrm{~d}$ \\
\hline $15(\mathrm{C} 1)$ & $12,33 \mathrm{hi}$ & $16,00 \mathrm{efg}$ & $17,50 \mathrm{c}-\mathrm{f}$ & $19,83 \mathrm{bcd}$ & $16,42 \mathrm{c}$ \\
\hline $30(\mathrm{C} 2)$ & $14,83 \mathrm{fgh}$ & $17,17 \mathrm{c}-\mathrm{f}$ & $20,67 \mathrm{bc}$ & $21,83 \mathrm{~b}$ & $18,63 \mathrm{~b}$ \\
\hline 45 (C3) & $16,67 \mathrm{~d}-\mathrm{g}$ & 19,17 b-e & $20,50 \mathrm{bc}$ & $27,00 \mathrm{a}$ & $20,83 \mathrm{a}$ \\
\hline \multirow[t]{2}{*}{ Rata-rata } & $13,25 \mathrm{~d}$ & $16,46 \mathrm{c}$ & $18,17 \mathrm{~b}$ & $21,50 \mathrm{a}$ & \\
\hline & & $\mathrm{BNJ} \mathrm{C} \& \mathrm{~N}=$ & & $\overline{\mathrm{BNJ}}$ &, 65 \\
\hline
\end{tabular}

Angka-angka pada baris dan kolom yang diikuti huruf kecil yang sama menandakan tidak berbeda nyata menurut uji lanjut BNJ taraf $5 \%$.

Serbuk cangkang telur pada penelitian ini mampu meningkatkan $\mathrm{pH}$ tanah yaitu dari $\mathrm{pH}$ awal 6 dan setelah pemberian mencapai $\mathrm{pH}$ 6,1-6,5. Peningkatan $\mathrm{pH}$ tersebut juga berdampak pada peningkatan hasil buah tomat. Hal ini dikarenakan pada kondisi $\mathrm{pH}$ yang ideal tersebut, unsur-unsur hara yang terdapat di dalam tanah menjadi tersedia dan dapat diserap baik oleh tanaman (Gunawam, 2019). Selain itu, tingginya kandungan kalsium pada serbuk cangkang telur ayam membantu perakaran untuk meningkatkan penyerapan unsur hara seperti unsur fosfor $(\mathrm{P})$ dan kalium $(\mathrm{K})$ yang didapatkan dari pupuk NPK. Muhajir (2017) menambahkan bahwa semakin tinggi dosis pupuk NPK maka semakin tinggi jumlah buah tomat.

\section{Berat Buah Per Buah (g)}

Hasil analisis menunjukkan bahwa pengaruh utama perlakuan serbuk cangkang telur ayam dan pupuk NPK 16:16:16 berpengaruh nyata terhadap berat buah per buah dapat dilihat pada Tabel 4. Tabel 4 menunjukkan bahwa perlakuan serbuk cangkang telur ayam $45 \mathrm{~g} / \operatorname{tanaman}$ (C3) nyata memberikan berat buah per buah terberat yaitu $41,03 \mathrm{~g}$, tidak berbeda nyata dengan serbuk cangkang telur ayam $30 \mathrm{~g} / \operatorname{tanaman}(\mathrm{C} 2)$ namun berbeda nyata dengan perlakuan lainnya. Pemupukan unsur kalsium (Ca) juga dapat berpengaruh terhadap hasil produksi tanaman tomat, yaitu meningkatnya volume dan bobot buah tomat (Lingga dan Marsono, 2013).

Tabel 4 juga menunjukkan bahwa perlakuan pupuk NPK 16:16:16 berpengaruh nyata terhadap berat buah per buah dengan perlakuan pupuk NPK 16:16:16 $30 \mathrm{~g} /$ tanaman (N3) menghasilkan rerata terberat 40,07 g, tidak berbeda nyata dengan perlakuan $\mathrm{C} 1, \mathrm{C} 2$ dan C3 namun berbeda nyata dengan perlakuan kontrol (C0).

Menurut Iskandar (2010), penggunaan pupuk anorganik yang berimbang dapat meningkatkan pertumbuhan dan hasil tanaman serta dapat memberikan tingkat produktifitas yang tinggi. Pupuk NPK merupakan pupuk majemuk yang memiliki 3 kandungan yaitu $\mathrm{N}$, $\mathrm{P}$, dan $\mathrm{K}$ yang seimbang. Nitrogen $(\mathrm{N})$ sebagai bahan pembentuk klorofil daun yang sangat diperlukan dalam proses fotosisntesis daun, selain itu nitrogen $(\mathrm{N})$ juga sebagai pembentuk senyawa asam-asam amino dan protein untuk pertumbuhan tanaman. Fosfor (P) sangat diperlukan untuk energi pertumbuhan (ATP) termasuk pembentukan biji, sementara kalium (K) memacu transkolasi hasil fotosintesis dari daun ke bagian lain tanaman dan berperan untuk pembentukan karbohidrat tanaman. Menurut Sutedjo (2010) unsur fosfor (P) mampu meningkatkan proses fotosintesis yang 
selanjutnya akan berpengaruh terhadap peningkatan berat buah tomat.

Tabel 4. Berat Buah Per Buah Tomat dengan Perlakuan Serbuk Cangkang Telur Ayam dan Pupuk NPK 16:16:16 (g)

\begin{tabular}{|c|c|c|c|c|c|}
\hline \multirow{2}{*}{$\begin{array}{c}\text { Cangkang telur ayam } \\
\text { (g/tanaman) }\end{array}$} & \multicolumn{4}{|c|}{ Pupuk NPK 16:16:16 (g/tanaman) } & \multirow{2}{*}{ Rata-rata } \\
\hline & 0 (N0) & $10(\mathrm{~N} 1)$ & $20(\mathrm{~N} 2)$ & $30(\mathrm{~N} 3)$ & \\
\hline $0(\mathrm{C} 0)$ & 36,03 & 35,56 & 38,37 & 38,08 & $37,01 \mathrm{c}$ \\
\hline $15(\mathrm{C} 1)$ & 38,02 & 37,97 & 40,34 & 38,58 & $38,73 \mathrm{bc}$ \\
\hline $30(\mathrm{C} 2)$ & 38,70 & 38,26 & 39,77 & 41,37 & $39,53 \mathrm{ab}$ \\
\hline $45(\mathrm{C} 3)$ & 39,23 & 41,42 & 41,22 & 42,24 & $41,03 \mathrm{a}$ \\
\hline Rata-rata & $37,99 \mathrm{~b}$ & $38,30 \mathrm{ab}$ & $39,93 \mathrm{a}$ & $40,07 \mathrm{a}$ & \\
\hline $\mathrm{KK}=5$, & \multicolumn{4}{|c|}{$\mathrm{BNJ} C \& N=2,17$} & \\
\hline
\end{tabular}

Angka-angka pada baris dan kolom yang diikuti huruf kecil yang sama menandakan tidak berbeda nyata menurut uji lanjut BNJ taraf $5 \%$.

Berat buah per buah juga dipengaruhi oleh faktor lingkungan seperti suhu udara yang mempengaruhi pertumbuhan dan produksi tanaman (Nurjayanti, dkk, 2012). Pada saat pembentukan buah (bulan Mei dan Juni), rerata suhu di Kota Pekanbaru yaitu $33,7^{\circ} \mathrm{C}$ dan $32,4^{\circ} \mathrm{C}$. Suhu tersebut diatas batas optimal untuk perkembangan tanaman tomat, sehingga pembentukan buah tomat terhambat. Menurut Anomsari dan Prayudi (2012) suhu yang optimal untuk pertumbuhan tomat ialah antara $20-27^{\circ} \mathrm{C}$. Jika suhu lebih dari $30^{\circ} \mathrm{C}$, maka mengakibatkan terhambatnya pembentukan buah tomat.

\section{Berat Buah Per Tanaman (g)}

Hasil analisis menunjukkan bahwa secara interaksi maupun utama perlakuan serbuk cangkang telur ayam dan pupuk NPK 16:16:16 berpengaruh nyata terhadap berat buah per tanaman (Tabel 5).

Tabel 5. Berat Buah Per Tanaman Tomat dengan Perlakuan Serbuk Cangkang Telur Ayam dan Pupuk NPK 16:16:16 (buah)

\begin{tabular}{|c|c|c|c|c|c|}
\hline \multirow{2}{*}{$\begin{array}{l}\text { Cangkang telur ayam } \\
\text { (g/tanaman) }\end{array}$} & \multicolumn{4}{|c|}{ Pupuk NPK 16:16:16 (g/tanaman) } & \multirow{2}{*}{ Rata-rata } \\
\hline & 0 (N0) & $10(\mathrm{~N} 1)$ & $20(\mathrm{~N} 2)$ & $30(\mathrm{~N} 3)$ & \\
\hline $0(\mathrm{C} 0)$ & $327,08 \mathrm{i}$ & $480,25 \mathrm{hi}$ & $534,97 \mathrm{gh}$ & $660,57 \mathrm{efg}$ & $500,72 \mathrm{~d}$ \\
\hline $15(\mathrm{C} 1)$ & 469,30 hi & $605,50 \mathrm{fgh}$ & $705,17 \mathrm{c}-\mathrm{f}$ & $762,50 \mathrm{~b}-\mathrm{e}$ & $635,62 \mathrm{c}$ \\
\hline $30(\mathrm{C} 2)$ & $567,13 \mathrm{fgh}$ & $676,28 \mathrm{~d}-\mathrm{g}$ & $820,65 \mathrm{bcd}$ & $900,80 \mathrm{~b}$ & $741,22 \mathrm{~b}$ \\
\hline 45 (C3) & $651,02 \mathrm{efg}$ & 794,00 b-e & $846,58 \mathrm{bc}$ & $1.140,67 \mathrm{a}$ & $858,07 \mathrm{a}$ \\
\hline Rata-rata & $503,63 \mathrm{~d}$ & $639,01 \mathrm{c}$ & $726,84 \mathrm{~b}$ & $866,13 \mathrm{a}$ & \\
\hline \multicolumn{2}{|c|}{$\mathrm{KK}=7,4 \overline{8 \%}$} & \multicolumn{2}{|c|}{ BNJ C\&N $=56,69$} & \multicolumn{2}{|c|}{$\mathrm{BNJ} C \mathrm{CN}=155,61$} \\
\hline
\end{tabular}

Angka-angka pada baris dan kolom yang diikuti huruf kecil yang sama menandakan tidak berbeda nyata menurut uji lanjut BNJ taraf $5 \%$.

Tabel 5 menunjukkan perlakuan serbuk cangkang telur ayam $45 \mathrm{~g} /$ tanaman dan pupuk NPK $\quad 16: 16: 16 \quad 30 \quad$ g/tanaman $\quad(\mathrm{C} 3 \mathrm{~N} 3)$ menunjukkan berat buah pertanaman tertinggi yaitu $1.140,67 \mathrm{~g}$, dan berbeda nyata dengan perlakuan lainnya. Hal ini menunjukkan bahwa perlakuan serbuk cangkang telur ayam $45 \mathrm{~g} /$ tanaman dan pupuk NPK 16:16:16 30 $\mathrm{g} /$ tanaman telah memenuhi kebutuhan unsur hara tanaman tomat. Kandungan kalsium pada cangkang telur ayam yang tinggi berperan dalam pembentukan rambut akar, sehingga tanaman mampu menyerap unsur hara yang diberikan oleh pupuk NPK dengan optimal.

Salah satu unsur hara yang dibutuhkan tanaman tomat dalam pembentukan dan pemasakan buah adalah unsur fosfor. Unsur hara yang terkandung dalam serbuk cangkang telur selain kalsium yaitu fosfor yang berfungsi dalam proses pemasakan buah. Unsur fosfor pada cangkang telur ayam yaitu $0,65 \%$ sehingga semakin tinggi dosis serbuk cangkang telur yang diberikan maka semakin tinggi juga unsur fosfor yang dapat diserap oleh tanaman sehingga semakin banyak buah tomat yang dihasilkan.

Unsur hara kalsium juga berperan dalam meningkatkan kualitas buah dengan mengurangi gangguan fisiologis, meningkatkan kekuatan buah, dan memperpajang umur simpan buah tomat (Abbasi dkk., 2013). Serbuk cangkang telur 
ayam yang diberikan mampu meningkatkan kualitas buah sehingga buah tidak rentan terhadap hama dan penyakit. Pada penelitian ini terlihat bahwa perlakuan serbuk cangkang telur ayam dosis $15 \mathrm{~g} / \operatorname{tanaman}(\mathrm{C} 1)$ mampu menekan penyakit blossom end rot (BER) hingga $68,07 \%$. Semakin tinggi dosis serbuk cangkang telur ayam, maka kemampuan untuk menekan serangan penyakit BER juga meningkat. Pada dosis 30 dan $45 \mathrm{~g} /$ tanaman (C2-C3) dapat menekan serangan penyakit BER sampai $100 \%$.

Menurut Syahren, dkk (2012) menyatakan bahwa aplikasi serbuk cangkang telur ayam dapat mengurangi timbulnya blossom end rot secara drastis. Peranan unsur kalsium pada tanaman menurut Rosmarkam dan Yuwono (2012) salah satunya adalah untuk meningkatkan ketahanan tanaman. Hal tersebut disebabkan dalam sistem metabolisme tanaman dihasilkan senyawa metabolit sekunder yang dapat menghambat perkembangan patogen. Unsur kalium pada pupuk NPK juga berperan dalam mencegah timbulnya penyakit BER. Kalium (K) berperan dalam mengaktifasi enzim-enzim yang berperan dalam metabolisme dan biosintesis (Wijaya, 2013).

Selain itu penambahan pupuk NPK 16:16:16, melengkapi kebutuhan unsur hara lain seperti nitrogen dan kalium. Unsur hara $\mathrm{N}$, $\mathrm{P}$, dan $\mathrm{K}$ pada tanaman dapat mempercepat pembungaan, perkembangan biji dan buah, membantu pembentukan karbohidrat, protein, lemak dan berbagai persenyawaan lainya (Baharuddin, 2016). Pemberian pupuk NPK juga sangat mempengaruhi hasil produksi dari tanaman tomat. Menurut Subhan, dkk (2009) bahwa setiap unsur hara yang terkandung di dalam pupuk NPK majemuk mendukung berbagai proses metabolisme sel, fotosintesis, dan respirasi sel sehingga dapat meningkatkan hasil produksi buah tomat.

\section{KESIMPULAN DAN SARAN}

\section{Kesimpulan}

1. Pada kombinasi perlakuan serbuk cangkang telur ayam dan pupuk NPK 16:16:16 meenunjukkan adanya pengaruh pada komponen hasil meliputi jumlah buah per tanaman dan bobot buah pertanaman.

2. Perlakuan serbuk cangkang telur ayam 45 g/tanaman mampu meningkatkan jumlah buah dan bobot buah pertanaman 54,3\% dan bobot buah $71,3 \%$ dibanding dengan perlakuan control

3. Perlakuan pupuk NPK 16:16:16 30 g/tanaman ampu meningkatkan jumlah buah $62,2 \%$ dan bobot buah $72 \%$ dibanding dengan perlakuan kontrol.

\section{Saran}

Dilakukan penelitian lanjutan dengan perlakuan serbuk cangkang telur ayam dan pupuk NPK 16:16:16 terhadap tanaman tomat pada tanah yang memiliki kemasaman tanah yang tinggi seperti tanah gambut dan PMK. Penambahan parameter persentase bunga menjadi buah terhadap suhu tingggi didataran rendah.

\section{DAFTAR PUSTAKA}

Abbasi, N. A., L. Zafar, H. A. Khan, and A. A. Qureshi. 2013. Effects of Naphthalene Acetic Acid and Calcium Chloride Application on Nutrient Uptake, Growth, Yield and Post Harvest Performance of Tomato Fruit. Journal Bot, 45 (3): 1581-1587.

Anomsari, S. dan Prayudi. 2012. Budidaya Tomat. Balai Pengkajian Teknologi Pertanian Jawa Tengah, Semarang.

Baharuddin, R. 2016. Respon Pertumbuhan dan Hasil Tanaman Cabai (Capsicum annum L.) terhadap Pengurangan Dosis NPK 16:16:16 dengan Pemberian Pupuk Organik. Jurnal Dinamika Pertanian, 32(2): 115-124.

Barman, M., M. S. Lalit, P. D. Siba, and K. R. Raj. 2014. Effect of Applied Lime and Boron on The Availability of Nutrients in An Acid Soil. Journal of Plant Nutrition, 37 (15): 357-373.

Dahang, D., R. R. Winardi, M. R. R. Lubis. Efek Pupuk Cair Kalsium terhadap Pertumbuhan dan Produksi Tanaman Kentang (Solanum tuberosum L.). Jurnal Agroteknosains, 3(2): 33-38.

Datta, S., C. M. Kim, M. Pernas, N. D. Pires, H. Proust, T. Tam, P. Vijayakumar, L. Dolan. 2011. Root Hairs: Development, Growth and Evolution at The Plant-soil Interface. Journal of Plant and Soil, 346 (1): $1-14$

Duaja, M. D. 2012. Pengaruh Bahan dan Dosis Kompos Cair terhadap Pertumbuhan Selada (Lactuca sativa L.). Jurnal Agroekoteknologi, 1(1): 37-45. 
Gary, D., D. V. M. Butcher dan R. Miles. 2009. Ilmu Unggas Jasa Ekstensi Koperasi. Lembaga Ilmu Pangan dan Pertanian, Universitas Florida, Gainesville.

Iskandar, D. 2010. Pengaruh Dosis Pupuk NPK terhadap Pertumbuhan dan Produksi Tanaman Jagung Manis di Lahan Kering. Online pada: http://www.iptek.net.id. Diakses Tanggal 17 September 2019.

Lingga, P. dan Marsono. 2013. Petunjuk Penggunaan Pupuk. Edisi Revisi. Penebar Swadaya, Jakarta.

Marliah, A. 2012. Pengaruh Varietas dan Jarak Tanam terhadap Pertumbuhan Kedelai (Glycine $\max$ (L.) Merril). Jurnal Agrista, 16(1): 22-28.

Muhajir, Marlina dan Agusni. 2017. Pengaruh Penggunaan Pupuk Daun Bayfolan dan Pupuk NPK terhadap Pertumbuhan dan Hasil Tanaman Tomat (Solanum lycopersicum L.). Jurnal Agrotropika Hayati, 4(3): 194-213.

Nurjayanti, D. Zulfita, dan D. Raharjo. 2012. Pemanfaatan Tepung Cangkang Telur sebagai Substitusi Kapur dan Kompos Keladi terhadap Pertumbuhan dan Hasil Cabe Merah pada Tanah Aluvial. Jurnal Sains Mahasiswa Pertanian, 1 (1): 16-21.

Prasetya, B., S. Kurniawan dan M. Febrianingsih. 2009. Pengaruh Dosis dan Frekuensi Pupuk Cair terhadap Serangan $\mathrm{N}$ dan Pertumbuhan Sawi (Brassica Juncea L) pada Entisol. Jurnal Agritek, 17(5): 1022-1029.

Purwati, E. 2009. Daya Hasil Tomat Hibrida (F1) di Dataran Medium. Jurnal Holtikultura, 2(1): 125-130.

Rosmarkam dan Yuwono. 2012. Ilmu Kesuburan Tanah. Kanisius, Yogyakarta.

Subhan, N. Nurtika dan N. Gunadi. 2009. Respons Tanaman Tomat terhadap Penggunaan Pupuk Majemuk NPK 1515-15 pada Tanah Latosol pada Musim Kemarau. Jurnal Hortikultura, 19(1): 4048.

Sutedjo, M. 2010. Pupuk dan Cara Pemupukan. Rineka Cipta, Jakarta.

Syahren, A. M., N. C. Wong, and S. Mahmud. 2012. The Efficacy of Calcium Formulation for Treatment of Tomato Blossom-End Rot. Journal Tropical Agriculture and Foundation of Sience, 40(1): 89-98.

Syam, Z. Z., K. Amiruddin dan Musdalifah. 2014. Pengaruh Serbuk Cangkang Telur
Ayam terhadap Tinggi Tanaman Kamboja Jepang (Adenium obesum). Jurnal Online Pendididkan Biologi, 3(14): 9-15.

Widodo, H. H. dan Sudradjat. 2016. Peranan Pupuk Kalsium pada Tanaman Kelapa Sawit (Elaeis guineensis Jacq.) Belum Menghasilkan Role of Calcium Fertilizer on Young Plant of Oil Palm (Elaeis guinensis Jacq.). Bul. Agrohorti, 4(3): 276-281.

Wijaya, K. A. 2013. Aplikasi Pupuk Lewat Daun pada Tanaman Kailan. Jurnal Ilmu Pertanian, 11(1): 77-79. 
